\title{
Solvatochromism of 2-(3-coumaroyl)-benzopyrylium dye and its di-substituted derivatives
}

\author{
E.V.Sanin ${ }^{* * *}$, A.I.Novikov ${ }^{* * *}$, A.D.Roshal ${ }^{* * *}$ \\ "State Scientific Institution "Institute for Single Crystals", National \\ Academy of Sciences of Ukraine, 60 Lenin Ave., 61001 Kharkiv, Ukraine \\ "*: Institute of Chemistry at V.Karazin Kharkiv National University, \\ 4 Svoboda Sq., 61022 Kharkiv, Ukraine \\ *** Guard Department at National Technical University "Kharkiv \\ Polytechnic Institute", 192 Poltavski Shlakh St., 61034 Kharkiv, Ukraine
}

\section{Received April 4, 2013}

The electronic structure of 2-(3-coumaroyl)-benzopyrylium perchlorate (CBP) and its di-substituted derivatives, has been investigated the experimental and theoretical analysis of spectral properties of these compounds in various media. It was found that spectral behavior of CBP and its derivatives depend on two solvent properties - nucleophility, which stabilizes cations in the ground state, and polarizability, which stabilizes cations in the Frank-Condon excited state. The growth of nucleophility and polarizability parameters of solvents leads, correspondingly, to hypsochromic and bathochromic shifts of CBP long-wavelength absorption bands. Spectral manifestations of the solvent nucleophility appear in CBP derivatives with strong inter-fragmental charge transfer upon excitation resulting in substantial delocalization of the positive charge.

Изучено электронное строение перхлората 2-(3-кумароил)-бензопирилия (CBP) и его дизамещенных производных, проведен экспериментальный и теоретический анализ спектральных свойств этих соединений в различных средах. Обнаружено, что спектральное поведение СВР зависит от двух свойств растворителей - нуклеофильности, которая стабилизирует катионы в основном состоянии, и поляризуемости, стабилизирующей их во Франк-Кондоновском возбужденном состоянии. Увеличение параметров нуклеофильности и поляризуемости растворителей приводит, соответственно, к гипсохромному и батохромному смещению длинноволновых полос поглощения СВР. Спектральные проявления нуклеофильности растворителя наблюдаются у производных СВР со значительным межфрагментным переносом заряда при возбуждении, где происходит значительная делокализация положительного заряда.

Сольватохромія 2-(3-кумароїл)-бензопірилієвого барвника та його дизаміщених похідних. Е.В.Санін, О.І.Новиков, О.Д.Рошаль.

Досліджено електронну будову перхлорату 2-(3-кумароїл)-бензопірилію (CBP) та його дизаміщених похідних, проведено експериментальний та теоретичний аналіз спектральних властивостей цих сполук у різних середовищах. Показано, що спектральна поведінка CBP залежить від двох властивостей розчинників - нуклеофільності, що стабілізує катіони в основному стані, і поляризовності, яка стабілізує їх Франк-Кондоновський збуджений стан. Зростання параметрів нуклеофільності та поляризовності розчинників призводить, відповідно, до гіпсохромного і батохромного зсувів довгохвильових смуг поглинання СВР. Спектральні прояви нуклеофільності розчинника спостерігаються у похідних СBР, що мають значний міжфрагментний перенос заряду при збудженні і де відбувається значна делокалізація позитивного заряду. 


\section{Introduction}

Derivatives of benzopyrylium salts are photochromes and pH-sensors [1], whose spectral properties depend on medium parameters [2,3]. Coumarins are known dyes, which are also widely used as fluorescent markers $[4,5]$.

Compounds under investigation, 2-(3coumaroyl)-benzopyrylium perchlorates (Fig. 1) (CBP), contain both benzopyrylium (BP) and coumarin (C) fluorophores. Connection of BP fragment, which is cation and demonstrates electron-accepting ability, to $\mathrm{C}$ fragment playing a role of electron donor, results in inter-fragmental re-distribution of electronic density in the ground state.

The excitation and excited-state deactivation processes in CBP molecules are accompanied by additional inter-fragmental charge transfer (ICT), therefore longwavelength absorption and fluorescence bands in electronic spectra of these compounds are of charge-transfer nature. All the factors influencing ICT, the internal ones, such as changing the nature and the position of substituents in $\mathrm{BP}$ and $\mathrm{C}$ fragments, or the external ones, such as specific and non-specific interactions with solvent molecules, result in changing CBP spectral properties.

The presence of ICT phenomenon and its sensitivity to medium properties permit the use of CBP as sensors in different domains of science and technology. BP moiety could play a role of an antenna in the detection of medium nucleophility or membrane potential. C fragment is also sensitive to polarity and acid-base properties of environment. All these properties permit the use of CBP in analysis of complex solvent mixtures, in detection of properties of living cell membranes, as well as in environmental organic pollution analysis.

We have investigated the dependence of ICT on position and electron-donating ability of substituents in benzopyrylium and coumarin moieties (Scheme 1), as well as on environment effects simulated by organic solvents of different nucleophility, electrophility, polarizability and polarity.

\section{Materials and methods}

The compounds under investigations have been obtained by acid condensation of corresponding derivatives of 3 -acetylcoumarine and salicylic aldehyde. This method was used earlier in the synthesis of benzopyrylium salts [6]. The structure of ob-
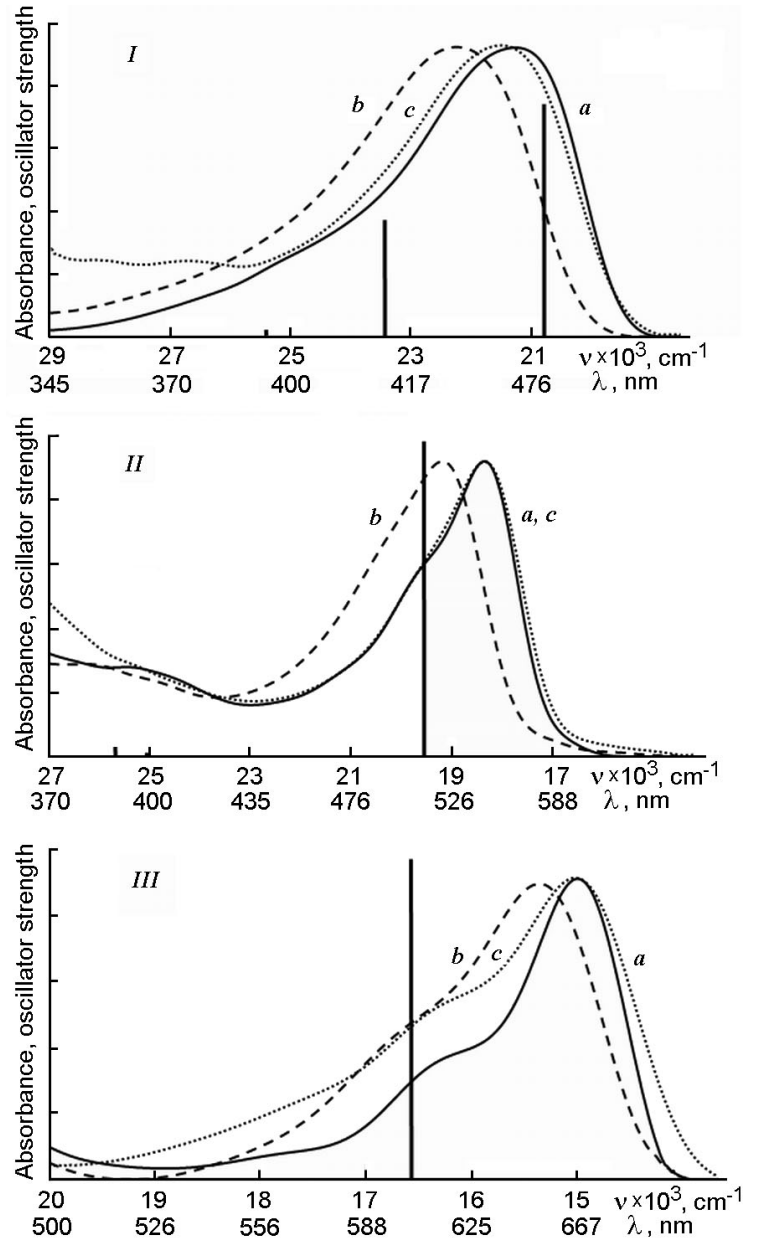

Fig. 1. Absorption spectra of I, II and III in dichloromethane (a), acetonitrile (b) and benzonitrile (c). Electronic transitions in theoretical spectra are depicted by vertical bars.

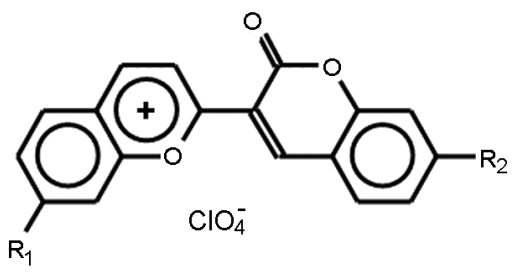

$$
\begin{array}{lll}
I & \mathrm{R}_{1}=\mathrm{H} & \mathrm{R}_{2}=\mathrm{H} \\
I I & \mathrm{R}_{1}=\mathrm{OH} & \mathrm{R}_{2}=\mathrm{OH} \\
I I I & \mathrm{R}_{1}=\mathrm{N}(\mathrm{Me})_{2} & \mathrm{R}_{2}=\mathrm{N}(\mathrm{Me})_{2}
\end{array}
$$

Scheme 1. Molecular structures of 2-(3-coumaroyl)-benzopyrylium cations.

tained compounds was proved by mass and ${ }^{1} \mathrm{H}$ NMR spectrometry.

Absorption spectra have been registered using a Hitachi U3210 spectrophotometer. Solvents for solvatochromic measurements were dried and purified according to methods previously described [7]. The treatment of the absorption spectra and the calcula- 
Table 1. Spectral parameters of CBP derivatives in selected solvents*

\begin{tabular}{|c|c|c|c|c|c|c||}
\hline \multicolumn{2}{||c|}{ Solvent } & $v_{a b s}, \mathrm{~nm}$ & $\lambda_{a b s}, \mathrm{~cm}^{-1}$ & $\Delta v_{\text {hyps }}, \mathrm{cm}^{-1}$ & $\Delta v^{1 / 2}, \mathrm{~cm}^{-1}$ & $\lg \varepsilon$ \\
\hline \multirow{3}{*}{ I } & Dichloromethane & 21260 & 470 & 0 & 3675 & 3.43 \\
& Acetonitrile & 22260 & 449 & 1000 & 3765 & 3.68 \\
& Benzonitrile & 21580 & 463 & 320 & 3830 & 3.98 \\
\hline \multirow{2}{*}{ II } & Dichloromethane & 18260 & 548 & 0 & 2580 & 5.12 \\
& Acetonitrile & 19100 & 524 & 840 & 2885 & 5.32 \\
& Benzonitrile & 18440 & 542 & 180 & 2580 & 5.31 \\
\hline \multirow{3}{*}{ III } & Dichloromethane & 14980 & 668 & 0 & 1470 & 5.13 \\
& Acetonitrile & 15340 & 652 & 360 & 2150 & 4.84 \\
& Benzonitrile & 14980 & 668 & 0 & 2240 & 4.95 \\
\hline \hline
\end{tabular}

$* v_{a b s}, \lambda_{a b s}-$ position of long-wavelength band maximum in wave numbers and wavelengths, $\Delta v_{h y p s}$ - hypsochromic shifts of long-wavelength absorption band relatively $v_{a b s}$ in dichloromethane, $\Delta v^{1 / 2}$ - half-widths of long-wavelength absorption bands, lge - decimal logarithms of extinction coefficients in maxima of long-wavelength absorption bands.

tions of spectral characteristics have been made with Spectra DataLab package [8].

The geometry optimization of CBP molecules and the calculation of inter-fragmental electronic density distribution have been carried out using DFT and TD DFT levels of theory [9] with the B3LYP functional [10, 11] and cc-pVDZ basis set $[12,13]$ implemented in the GAUSSIAN 09 program package [14]. The solvent effect was included in the DFT (TD DFT) calculations at the level of the Polarized Continuum Model (PCM) (UAHF radii were used to obtain the molecular cavity) [15, 16].

\section{Results and discussion}

Absorption spectra of CBP are depicted on Fig. 1. It is obvious that the presence of electron-donating substituents in $\mathrm{BP}$ and $\mathrm{C}$ fragments results in substantial bathochromic shift of absorption bands. The bands of CBP derivatives are of another shape: their half-width is lower that that of unsubstituted compound, they demonstrate vibronic structure that shows more rigid structure of corresponding molecules. The high half-width of long-wavelength absorption band of I (Table 1) (1.5-2.0 times higher than half-widths of II and III) may be due to complex structure of this band.

On going from dichloromethane to more polar and nucleophilic solvent - acetonitrile, all CBP demonstrate hypsochromic shift of long-wavelength absorption band $\left(\Delta v_{\text {hyps }}\right.$ in Table 1$)$. However, such a spectral effect is absent on going from dichlo-

Table 2. Electronic and structural parameters of CBP

\begin{tabular}{|c|c|c|c|c|c|c|c|}
\hline & & \multicolumn{2}{|c|}{$\begin{array}{l}\text { Charges on } \mathrm{BP} \\
\text { fragment, } \bar{e}\end{array}$} & \multirow{2}{*}{$\begin{array}{c}\text { Inter- } \\
\text { fragmental } \\
\text { charge transfer } \\
\text { upon } \\
\text { excitation }{ }^{*}, \bar{e}\end{array}$} & \multicolumn{2}{|c|}{$\begin{array}{c}\text { Inter-fragmental bond } \\
\pi \text {-orders }\end{array}$} & \multirow{2}{*}{$\begin{array}{c}\text { Dipole } \\
\text { moment } \\
\text { changes, Db }\end{array}$} \\
\hline & & $S_{0}$ state & $S_{1}{ }^{\mathrm{FC}}$ state & & $S_{0}$ state & $S_{1}{ }^{\mathrm{FC}}$ state & \\
\hline \multirow[t]{3}{*}{$\mathbf{I}$} & gaseouse phase & 0.706 & 0.426 & 0.280 & 0.321 & 0.314 & 1.05 \\
\hline & dichloromethane & 0.757 & 0.468 & 0.289 & 0.314 & 0.324 & -1.67 \\
\hline & acetonitrile & 0.765 & 0.480 & 0.285 & 0.303 & 0.327 & -2.11 \\
\hline \multirow[t]{3}{*}{ II } & gaseouse phase & 0.690 & 0.575 & 0.115 & 0.324 & 0.296 & -1.38 \\
\hline & dichloromethane & 0.740 & 0.576 & 0.164 & 0.318 & 0.321 & -2.14 \\
\hline & acetonitrile & 0.748 & 0.576 & 0.172 & 0.317 & 0.324 & -2.26 \\
\hline \multirow[t]{3}{*}{ III } & gaseouse phase & 0.685 & 0.637 & 0.047 & 0.330 & 0.316 & -0.68 \\
\hline & dichloromethane & 0.727 & 0.629 & 0.098 & 0.324 & 0.329 & -0.79 \\
\hline & acetonitrile & 0.734 & 0.627 & 0.107 & 0.323 & 0.332 & -0.83 \\
\hline
\end{tabular}

* Listed values present positive charge transfer $(\bar{e})$ from benzopyrylium onto coumarin fragment. 
Table 3. Theoretical spectral parameters of CBP derivatives

\begin{tabular}{|c|c|c|c|c|c|c|}
\hline & \multirow{2}{*}{ Medium } & \multirow{2}{*}{$\begin{array}{c}\text { Transition } \\
\text { number }\end{array}$} & \multicolumn{2}{|c|}{ Transition parameters } & \multirow{2}{*}{$\begin{array}{l}\text { Oscillator } \\
\text { strength }\end{array}$} & \multirow[t]{2}{*}{ Configuration interaction } \\
\hline & & & $E, \mathrm{eV}$ & $\lambda, \mathrm{nm}$ & & \\
\hline \multirow[t]{9}{*}{$\mathbf{I}$} & \multirow[t]{3}{*}{ Gaseous phase } & 1 & 2.47 & 502 & 0.151 & \multirow{3}{*}{$\begin{array}{c}0.644 \chi_{1->1^{\prime}}+0.289 \chi_{2->1^{\prime}} \\
-0.291 \chi_{1->1^{\prime}}+0.642 \chi_{2->1^{\prime}} \\
0.701 \chi_{2->1^{\prime}}\end{array}$} \\
\hline & & 2 & 2.91 & 427 & 0.604 & \\
\hline & & 3 & 3.18 & 390 & 0.023 & \\
\hline & \multirow[t]{3}{*}{ Dichloromethane } & 1 & 2.57 & 483 & 0.708 & $0.707_{1->1^{\prime}}$ \\
\hline & & 2 & 2.91 & 426 & 0.358 & $0.705_{\chi 2->1^{\prime}}$ \\
\hline & & 3 & 3.15 & 394 & 0.016 & $0.702_{3 \chi->1^{\prime}}$ \\
\hline & \multirow[t]{3}{*}{ Acetonitrile } & 1 & 2.57 & 482 & 0.810 & $0.705 \chi_{1->1^{\prime}}$ \\
\hline & & 2 & 2.93 & 423 & 0.297 & $0.703 \chi_{2->1^{\prime}}$ \\
\hline & & 3 & 3.15 & 394 & 0.015 & $0.701 \chi_{3->1^{\prime}}$ \\
\hline \multirow[t]{9}{*}{ II } & \multirow[t]{3}{*}{ Gaseous phase } & 1 & 2.62 & 474 & 0.617 & \multirow{3}{*}{$\begin{array}{c}0.694 \chi_{1->1^{\prime}}-0.127 \chi_{2->1^{\prime}} \\
0.127 \chi_{1->1^{\prime}}+0.691 \chi_{2->1^{\prime}} \\
0.663 \chi_{3->1^{\prime}}\end{array}$} \\
\hline & & 2 & 2.94 & 421 & 0.079 & \\
\hline & & 3 & 3.20 & 388 & 0.006 & \\
\hline & \multirow[t]{3}{*}{ Dichloromethane } & 1 & 2.43 & 511 & 0.866 & $0.704 \chi_{1->1^{\prime}}$ \\
\hline & & 2 & 3.10 & 399 & 0.010 & $0.634 \chi_{2->1^{\prime}}$ \\
\hline & & 3 & 3.19 & 388 & 0.030 & $0.632 \chi_{3->1^{\prime}}$ \\
\hline & \multirow[t]{3}{*}{ Acetonitrile } & 1 & 2.41 & 515 & 0.892 & $0.704 \chi_{1->1^{\prime}}$ \\
\hline & & 2 & 3.12 & 398 & 0.006 & $0.663 \chi_{2->1^{\prime}}$ \\
\hline & & 3 & 3.21 & 386 & 0.035 & $0.668 \chi_{3->1^{\prime}}$ \\
\hline \multirow[t]{9}{*}{ III } & \multirow[t]{3}{*}{ Gaseous phase } & 1 & 2.31 & 536 & 0.735 & $0.703 \chi_{1->1^{\prime}}$ \\
\hline & & 2 & 2.81 & 441 & 0.042 & $0.691 \chi_{2->1^{\prime}}$ \\
\hline & & 3 & 3.09 & 402 & 0.001 & $0.660 \chi_{3->1^{\prime}}$ \\
\hline & \multirow[t]{3}{*}{ Dichloromethane } & 1 & 2.06 & 601 & 0.922 & $0.703 \chi_{1->1^{\prime}}$ \\
\hline & & 2 & 2.73 & 455 & 0.103 & $0.691 \chi_{2->1^{\prime}}$ \\
\hline & & 3 & 3.26 & 381 & 0.004 & $0.688 \chi_{3->1^{\prime}}$ \\
\hline & \multirow[t]{3}{*}{ Acetonitrile } & 1 & 2.03 & 610 & 0.943 & $0.703 \chi_{1->1^{\prime}}$ \\
\hline & & 2 & 2.71 & 458 & 0.119 & $0.694 \chi_{2->1^{\prime}}$ \\
\hline & & 3 & 3.28 & 378 & 0.012 & $0.672 \chi_{3->1^{\prime}}$ \\
\hline
\end{tabular}

romethane to benzonitrile solutions. Lippert constant values of benzonitrile and acetonitrile are similar that shows the same level of not-specific interactions between solvents and a solute. The solvents have also similar parameter of nucleophility (B), however benzonitrile does not form nucleophilic complexes with aromatic cations [3, 17, 18]. Therefore, different spectral behavior of CBP in mentioned solvents proves the stabilisation of CBP cations in the ground state by the nucleophilic solvation effect.

To analyze the spectral behaviour of CBP derivatives, quantum-chemical calculations of positive charge localization in the ground and Franc-Condon excited states have been carried out. Inter-fragmental charge transfer and dipole moment changes upon excitation, as well as theoretical spectral parame- ters of electronic transitions were also estimated. The calculations were made for CBP cations in gaseous phase, in acetonitrile and dichloromethane media, however only solvent polarity effect was taken into account. Results of the calculations are listed in Tables 2 and 3.

CBP are of planar structure, and, according to Table 2 , inter-fragmental $\pi$-bonding between $\mathrm{C}$ and BP fragments is very high in range of $0.30-0.33$. It results to substantial delocalization of the positive charge onto coumarin moiety of CBP, therefore a charge value on this fragment reaches $\sim+0.29-+0.31 \bar{e}$.

On going from gaseous to condensed phase, the positive charge on coumarin fragment decreases to $+0.24-+0.27 \bar{e}$, the inter-fragmental $\pi$-bonding orders also 
somewhat diminishes. Data in Table 2 show that the growth of solvent polarity also hinders delocalization of the positive charge and thus favours its concentration on benzopyrylium fragment. This phenomenon can result in strengthening specific interactions of CBP with solvents.

The excitation leads to inter-fragmental charge transfer (ICT). The maximal ICT is typical for unsubstituted CBP (I), and the positive charge on coumarin fragment becomes higher than that on the benzopyrylium fragment. In the case of II and III, ICT is weaker, but it increases with growth of medium polarity. Charge re-distribution upon excitation leads to some decrease of dipole moment in the excited state and to increase of $\pi$-bonding between fragments, that, in turn, increases rigidity of CBP cations.

Since the positive charge in the ground state is more localized than in the excited state, and dipole moment decreases upon excitation, it would be reasonable to conclude that stabilizing effect of polar and nucleophilic solvents is higher in the ground state. It would result in the increase of electronic transition energy and, correspondingly, in hypsochromic shift of long-wavelength absorption band.

Calculations of parameters of CBP electronic transitions (Table 3) have given a contrary result. They showed that, in spite of decreasing dipole moment upon excitation, the growth of medium polarity results in small bathochromic shift. In the experimental spectra discussed above, on the contrary, any noticeable band shift was not detected on going from dichloromethane to polar benzonitrile. On going further to polar and nucleophilic acetonitrile longwavelength bands undergo not bathochromic, but hypsochromic shift.

According to theoretical estimations, oscillator strengths of long-wavelength transitions increase with the growth of the medium polarity (Table 3). Corresponding extinction coefficients in experimental spectra of I and II show similar dependence (Table 1), however, III demonstrates an opposite spectral behavior.

The discrepancy of experimental and theoretical spectra indicates that the polarized continuum model used in calculations is not sufficient, and the influence of other specific and not specific interactions CBP solvent, stronger than solvent polarity effect, must be taken into account.

In addition to solvent polarity and nucleophility, spectral properties of CBP can depend on the polarizability of the medium. Moreover, dimethylamino substituents can manifest their electron-donating effect not only for $\mathrm{BP}$ or $\mathrm{C}$ fragments, but also for solvent molecules, and then, the influence of solvent electrophility may be expected.

To estimate all mentioned solvent effects, the linear regression analysis of positions of long-wavelength absorption bands was carried out according to the equation:

$$
v_{a b s}=y Y+p P+b B+e E,
$$

where $Y$ is solvent polarity $(Y=\varepsilon-1 / 2 \varepsilon+1)$, $P$ is polarizability $\left(P=n^{2}-1 / 2 n^{2}+1\right), B$ and $E$ are nucleophility and electrophility parameters, correspondingly $[19,20]$.

Depending on the solubility of CBP and its derivatives, from 6 to 10 organic solvents of different polarity, polarizability, nucleophility and electrophility were used. To avoid an ion association, concentrations of CBP solutions in range $2.0-6.0 \cdot 10^{-6} \mathrm{M}$ were investigated. Graphical results of solvatochromism investigations are presented on Fig. 2.

Fig. 2a shows that the long-wavelength band of I linearly depends on solvent nucleophility. The dependence obtained by regression analysis may be described by equation:

$$
v_{a b s}=6.35 \times \boldsymbol{B}+20430(r=0.986) .
$$

No reliable influence of other solvent parameters on absorption band position was detected. This phenomenon proofs our supposition about a small influence of solvent polarity in spectral behaviour of I. Similar complexes and, correspondingly, similar spectral behaviour were found in the case of 2-phenylbenzopyrylium salts [2,3]. Changing solvent nucleophility from 50 to 250 units results in hypsochromic shift by $\sim 1500 \mathrm{~cm}^{-1}$. Such a sensitivity permits to use I for detection of nucleophilic impurities in such solvents as hydrocarbons or to estimate a surface charge value on cell membranes.

Results of regression analysis for II and III showed a dependence of $v_{a b s}$ on solvent polarizability:

$$
\begin{aligned}
& v_{a b s}=21165-11980 \times \boldsymbol{P}(r=0.983) \text { (for II) } \\
& v_{a b s}=16425-6315 \times \boldsymbol{P}(r=0.980) \text { (for III). }
\end{aligned}
$$

Corresponding plots on Fig. $2 \mathrm{~b}$ and $2 \mathrm{c}$ show that the increase of polarizability results in bathochromic shift of absorption bands $\left(\Delta v_{\max }=1120\right.$ and $650 \mathrm{~cm}^{-1}$, corre- 

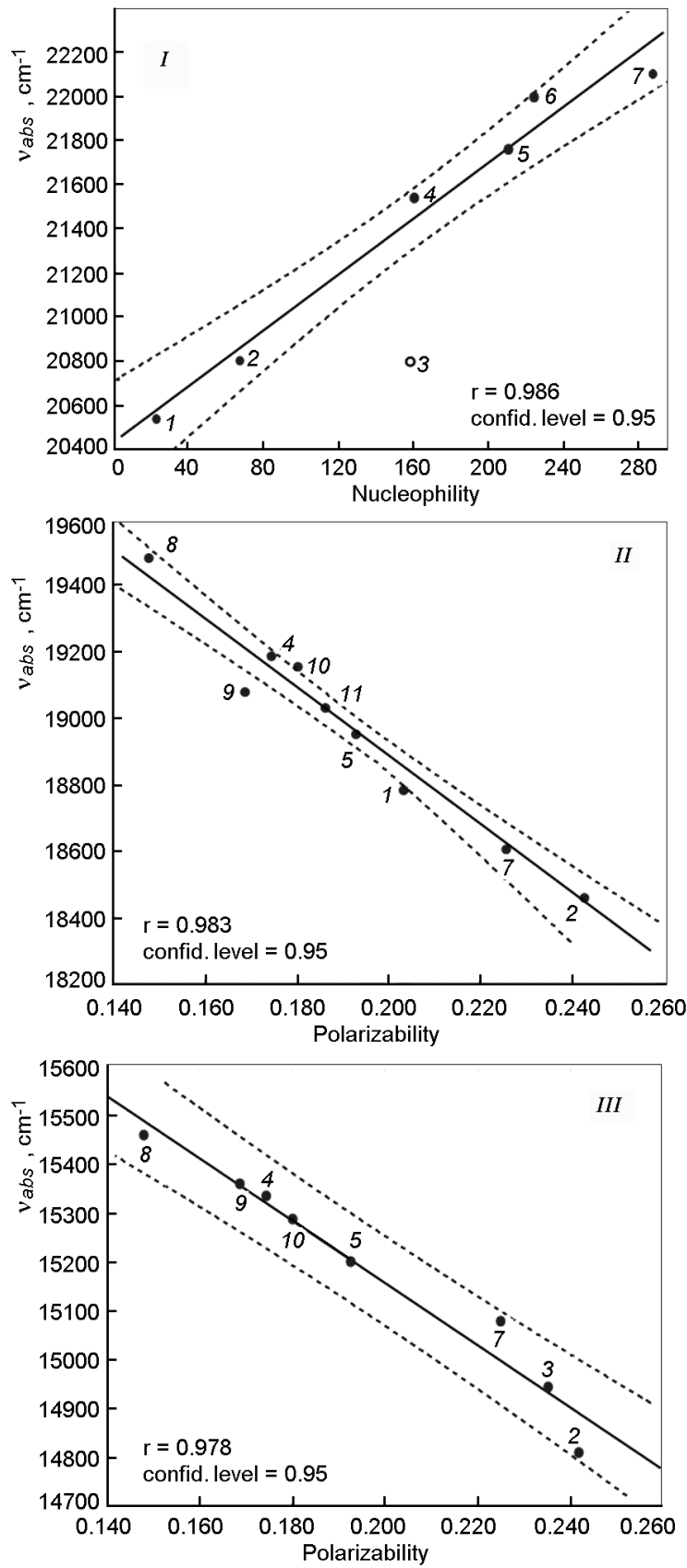

Fig. 2. Plots of band maxima in absorption spectra of I, II, III against solvent parameters. Regression bands for confidence level 0.95 are depicted by dashed lines. Solvents used: 1 - dichloromethane, 2 - nitrobenzene, 3 - benzonitrile, 4 - acetonitrile, 5 isobutanol, 6 - acetone, 7 - tetrahydrofurane, 8 - dimethylsulfoxide, 9 - methanol, 10 - acetone, 11 - isopropanol, 12 isobutanol.

spondingly). The influence of polarizability seems to be reasonable taking into account that the main type of not-specific interaction between CBP cations and solvent mole- cules is an ion-dipole interaction. Since positions of molecules in solvation sphere do not change themselves upon the excitation, solvent molecules with more polarizable electronic shells demonstrate quick response on re-distribution of electronic density in CBP cation, and hence, decrease its energy in the Frank-Condon excited state.

The positive solvatochromism observed in experimental investigations was not found in theoretical spectra, because solvent polarizability effects are not taken into account in used PCM routine.

Positions of long-wavelength bands of II and III in not-aromatic solvents do not demonstrate any dependence on solvent nucleophility. This phenomenon may be explained by the fact that the ICT upon excitation for II and III is 2-3 times smaller than that of I (Table 2). In the result, small changing positive charge on the BP fragment upon excitation shows similar stability of nucleophilic complexes with solvent molecules in the ground and excited states. Then, stabilizing effect of nucleophilic solvation would be similar in the both states, and no substantial influence of solvent nucleophility on CBP spectral properties would be observed.

It is necessary to take into account that the dependence of spectral properties of some benzopyrylium salts on solvent nucleophility is sometimes not linear $[2,3]$, and cannot be determined by regression analysis.

Returning to solvatochromic properties of $\mathbf{I}$, it is worth to note the absence of the dependence $v_{a b s}$ on polarizability parameter, although its influence must be typical for all the CBP cations. The analysis of experimental data shows that the equation $v_{a b s}=$ $f(P, B)$ has higher correlation coefficient than $v_{a b s}=f(B)$, however the polarizability parameter is of low reliability. Obviously, the stabilization effect of CBP in the ground state due to formation of nucleophilic complexes is substantially higher than the stabilization effect in the excited state due to polarizability of solvent molecules.

\section{Conclusions}

Summarizing the results mentioned above, it is possible to conclude that solvatochromism of CBP and its derivatives is due to two solvent properties - nucleophility, which stabilizes cations in the ground state, and polarizability, which stabilizes cations in the Frank-Condon excited state. 
The growth of these parameters leads, correspondingly, to hypsochromic and bathochromic shifts of long-wavelength absorption bands. Nucleophilic complexes of solvents must be characteristic for all CBP, however spectral manifestations of the nucleophility appear in CBP derivatives with strong ICP resulting in substantial delocalization of the positive charge and weakening nucleophilic interaction with solvent molecules. Theoretical calculations correctly predict a number and positions of absorption bands, but do not predict solvatochromic effects because they do not take into account specific interaction with solvents and their polarizabilities. From a practical standpoint, the most interesting and fruitful spectral effects are those of unsubstituted CBP with maximal ICT upon excitation, and further efforts in synthesis of CBP derivatives must be directed on making derivatives with higher localization of positive charge in the ground state and maximal possible inter-fragmental charge transfer upon the excitation.

\section{References}

1. F.Pina, M.J.Melo, A.J.Parola et al., Chem. Eur. J., 4, 2001 (1998).

2. A.D.Roshal, D.Yu.Minayev, V.L.Koval, A.I.Novikov, Opt. and Spectrosc., 85, 705 (1998).

3. A.D.Roshal, D.Yu.Minayev, Yu.F.Pedash, A.I.Novikov, Polish J. Chem., 76, 1301 (2002).

4. B.D.Wagner, Molecules, 14, 210 (2009).

5. R.Dondon, V.P.Khilya, A.D.Roshal, S.FeryForgues, New J. Chem., 23, 923 (1999).
6. P.Czreney, H.Hartmann, J.Prakt.Chem., 323, 505 (1983).

7. A.Weissberger, E.S.Proskauer, J.A.Riddik, E.E.Toops, Organic Solvents: Physical Properties and Methods of Purification, Inrescience Publishers Inc., New York, London (1955).

8. A.O.Doroshenko, Software Packet "Spectral Data Lab 3.1", Institute of Chemistry, Kharkiv Nat. Univ., Kharkiv (1999).

9. J.K.Labanowski, in: Density Functional Methods in Chemistry, Springer-Verlag, New York (1991).

10. A.D.Becke, J.Chem.Phys., 98, 5648 (1993).

11. C.Lee, W.Yang, R.G.Parr, Phys.Rev.B, 37, 785 (1988).

12. M.M.Francl, W.J.Pietro, W.J.Hehre et al., $J$. Chem. Phys., 77, 3654 (1972).

13. P.C.Hariharan, J.A.Pople, Theor.Chim.Acta, 28, 213 (1973).

14. M.J.Frisch, G.W.Trucks, H.B.Schlegel et al., Gaussian 09, revision C.02; Gaussian, Inc.:Wallingford, CT (2004).

15. J.Tomasi, M.Persico, Chem.Rev., 94, 2027 (1994).

16. V.Barone, M.Cossi, B.Mennucci, J.Tomasi, J. Chem. Phys., 107, 3210 (1997).

17. A.A.Ishchenko, V.A.Svidro, N.A.Derevianko, Dyes and Pigments, 10, 85 (1989).

18. M.Wohnert, S.Dahne, R.Radeglia, Adv.Mol. Relaxation and Interact.Proc., 11, 263 (1977).

19. I.A.Koppel, V.A.Palm, Reakts. Sposobnost Organich. Soed., 8, 291 (1971).

20. I.A.Koppel, A.I.Payu, Reakts. Sposobnost Organich. Soed., 11, 121 (1974). 